\section{Early Field Detection of Bolting in Celery}

\author{
Sylvie Jenni ${ }^{1}$, Isabelle Gamache ${ }^{1}$, John Christopher Côté ${ }^{2}$, and \\ Katrine A. Stewart ${ }^{2}$
}

\begin{abstract}
Additional index words. Apium graveolens, floral induction, inflorescence initiation, premature flowering, stem apex, vernalization

SUMMARY. Growers of early stalk celery (Apium graveolens var. dulce) often experience financial losses due to bolting (the premature and rapid elongation of the main celery stem) in temperate regions. A method was developed to provide early warning of bolting in field-grown celery, on the basis of two criteria, one visual and one microscopic, for inflorescence development. Bolting could be detected 40 days after transplanting using the visual criterion, and as early as $\mathbf{3 0}$ days after transplanting using the microscopic criterion. Early detection of bolting using the visual and microscopic criteria provided celery growers with periods of, respectively, 25 days and up to 35 days to consider harvesting earlier, before the length of the celery stems exceeded commercial standards. This method could be effective in minimizing financial losses due to bolting when coupled with agroeconomic studies.
\end{abstract}

S talk celery requires a relatively long and cool growing season (Pressman, 1997). In regions with short growing seasons, such as Quebec, celery plants are started in greenhouses and transplanted into the field 7-9 weeks later at the four- to fiveleaf stage. Earlier transplanting results in a longer growing season, increased yields, and better prices. However, early celery production often takes place in the cool weather conditions of spring, which increases the risk of bolting. Bolting is the premature rapid elongation of the main celery stem into a floral axis (i.e., during the first year for this normally biennial species). Bolting in celery is induced when plants are vernalized by exposure to temperatures below $14^{\circ} \mathrm{C}$ (Benoit et al., 1978; Pressman and Sachs, 1985), with optimal vernalizing temperatures ranging from 5 to $9{ }^{\circ} \mathrm{C}$ (Honma, 1959; Kinet et al., 1976). For bolting to occur, plants have to reach a minimum physiological age in order to be competent and to

${ }^{1}$ Horticulture Research and Development Centre, Agriculture and Agri-Food Canada, 430 Boul. Gouin, Saint-Jean-sur-Richelieu, Que., J3B 3E6, Canada.

${ }^{2}$ Department of Plant Science, Macdonald Campus of McGill University, 21111 Lakeshore road, Sainte-Annede-Bellevue, Que., H9X 3V9, Canada.

Agriculture and Agri-Food Canada, Saint-Jean-surRichelieu, Que., Contribution no. 335/2005.08.01.R This project was supported by a grant from le Conseil de recherche en pêche et agroalimentaire du Québec. Thanks to Jean-Claude Desrosiers, Luc Marchand, and Jean-François Dubuc for technical assistance. Use of trade names does not imply endorsement of the products named or criticism of similar ones not named.

${ }^{1}$ Reprint requests should be addressed to: jennis@agr. gc.ca perceive the vernalizing stimulus (e.g., the 17- to 20-leaf stage). This minimum physiological age corresponds to a temperature sum of $731^{\circ} \mathrm{C}$ and 714 to $840^{\circ} \mathrm{C}$ above $3{ }^{\circ} \mathrm{C}$ for ' $\mathrm{New}$ Dwarf White' and 'Celebrity', respectively (Ramin and Atherton, 1991). Once the stimulus is perceived, inflorescence is initiated (Pressman and Sachs, 1985) and the floral axis develops. Bolting in celery can be delayed or slowed down by exposing plants to long days during vernalization (Pressman and Negbi, 1980), or to temperatures above 16 ${ }^{\circ} \mathrm{C}$ (Benoit et al., 1978) or short days (Ramin and Atherton, 1994) after vernalization, a process called "devernalization." However, devernalization treatments can not be applied when the production phase of celery takes place in the open field.

The Canadian Food Inspection Agency (CFIA, 1999) has defined a stem length of $15.2 \mathrm{~cm}$ as the limit above which celery cannot be graded Canada No. 1 or No. 2 and is thus unmarketable. As a result, the period between perception and the point when the stem is too long is critical for management decisions about time to harvest. The objective of this study was to determine whether celery inflorescence initiation observed either visually (Pressman and Sachs, 1985) or microscopically (Roelofse et al., 1989,1994 ) could be combined with growth data to determine the optimal time to harvest.

\section{Materials and methods}

In 1999 and 2000, two groups of 'Florida 683' celery transplants (63 and $49 \mathrm{~d}$ old, respectively) were purchased from a local commercial transplant producer (Les Serres Lefort, Sainte-Clotilde, Que.). The transplants had been grown in a greenhouse under natural daylight, with air temperatures maintained at $20^{\circ} \mathrm{C}$ day $/ 15^{\circ} \mathrm{C}$ night. Irrigation and fertilization followed commercial guidelines (Tremblay and Sénécal, 1991). The transplants were then vernalized in growth chambers set at $10^{\circ} \mathrm{C}$ day $/ 5^{\circ} \mathrm{C}$ night temperatures, $60 \%$ relative humidity, and 16 -h photoperiod for $15 \mathrm{~d}$ to ensure that they would bolt.

Experiments were carried out on organic soil (Limno Humic Mesisol) at Agriculture and Agri-Food Canada's Sainte-Clotilde Research Sub-Station in Quebec (lat. $45^{\circ} 09^{\prime} \mathrm{N}$, long. $\left.73^{\circ} 4 \mathrm{l}^{\prime} \mathrm{W}\right)$. Prior to transplanting, the field was rototilled and fertilized with $110 \mathrm{~N}-17.5 \mathrm{P}-62.3 \mathrm{~K}$ on the basis of soil tests. The celery plants were transplanted on 20 May 1999 and 23 May 2000. The plants were irrigated as required, and herbicide and pesticide applications followed commercial guidelines (Centre de référence en agriculture et agroalimentaire du Québec, 2001).

The plots comprised four rows of plants spaced $60 \mathrm{~cm}$ apart between rows and $25 \mathrm{~cm}$ apart within rows, with the border plants used as guards.

In 1999 and 2000, 66 and 54 plants from each of four replicates were randomly sampled at 2 -week intervals beginning at the time of transplanting, with 264 and 216 plants from each of the four replicates left for final harvest on 12 and 7 Aug., respectively. Main stem length was measured from the stem plate to the tip of the heart, and mean stem length $( \pm$ SE) was plotted as a function of time throughout the growing season. Initial inflorescence

\begin{tabular}{llll}
\hline $\begin{array}{l}\text { Units } \\
\begin{array}{l}\text { To convert U.S. to SI, } \\
\text { multiply by }\end{array}\end{array}$ & U.S. unit & SI unit & $\begin{array}{l}\text { To convert SI to U.S., } \\
\text { multiply by }\end{array}$ \\
\hline 2.5400 & inch(es) & $\mathrm{cm}$ & 0.3937 \\
28.3495 & $\mathrm{OZ}$ & $\mathrm{g}$ & 0.0353 \\
$\left({ }^{\circ} \mathrm{F}-32\right) \div 1.8$ & ${ }^{\circ} \mathrm{F}$ & ${ }^{\circ} \mathrm{C}$ & $\left(1.8 \times{ }^{\circ} \mathrm{C}\right)+32$
\end{tabular}


development was visible to the naked eye at a stem length of $1.5 \mathrm{~cm}$ (Fig. 1). This stem-length threshold was considered the visual criterion for early development of inflorescence. In 2000 , the main stem apex was dissected under a binocular microscope (magnification $40 \times$ ) to determine the stage of early development of inflorescence, according to the scale previously defined by Roelofse et al. (1989). The discrete developmental stages of celery inflorescence ranged from 0 (no evidence of inflorescence development) to 7 (complete transition from a vegetative meristem to an inflorescence) (Roelofse et al., 1989, 1994). We considered stage 1 (initiation of inflorescence) of the main stem apex to be the microscopic criterion for celery floral induction. Stem length and fresh weight were measured in plants sampled during the growing season and at final harvest in plants trimmed to $35.6 \mathrm{~cm}$ high in accordance with commercial standards. Calculation of a recommended sample size based on post-factor analysis was performed with S-Plus Software (S-Plus 6.1 for Windows, Professional Edition, Release 1; Insightful Corp., Seattle, Wash.).

\section{Results and discussion}

The growth curves of the vernalized celery stems were very similar throughout the 1999 and 2000 growing seasons for the first $70 \mathrm{~d}$ after transplanting in the field (Fig. 2). As a result, the two dates inferred from the stem-length threshold associated with the visual or CFIA criterion were almost identical (only in 2000 could a date be inferred from the microscopic criterion) (Fig. 2). This suggests that the method developed here for early detection of bolting should be reliable under various annual climatic conditions. The divergence of the growth curves in the week prior to final harvest, with a greater mean stem length in 2000 (Fig. 2), could be the result of stronger vernalization stimuli in 2000 in response to lower spring temperatures. Mean ambient temperatures during May were $14.7^{\circ} \mathrm{C}$ in 1999 and $12.7^{\circ} \mathrm{C}$ in 2000 (Environment Canada, 2005). As early as $30 \mathrm{~d}$ after transplanting, a microscopic estimate of the proportion of bolting celery could be made. Alternately, an estimate could be made by counting the number of plants with a stem length that is $\geq 1.5$ $\mathrm{cm} 40-4 \mathrm{l} \mathrm{d}$ after transplanting. Based

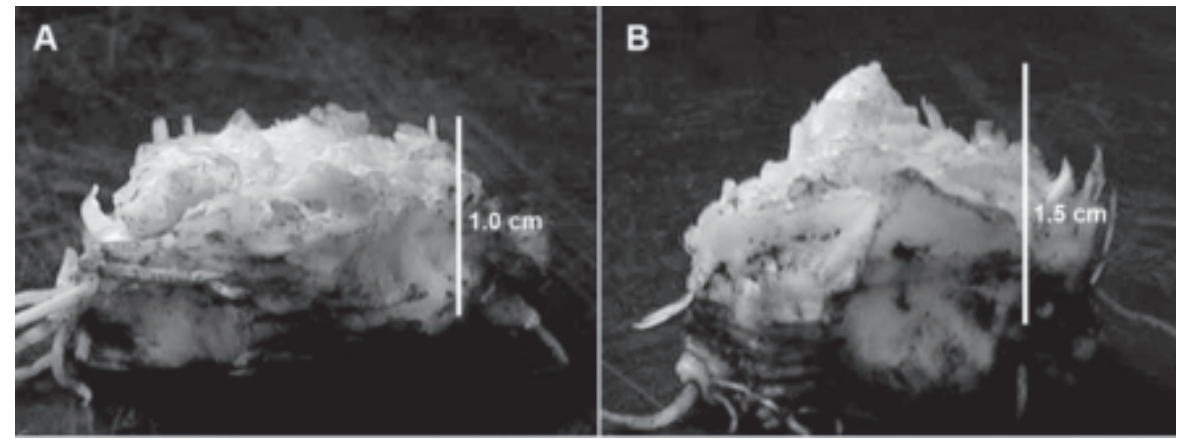

Fig. 1. Main stem apex of a 'Florida 683 ' celery plant (A) at $1.0 \mathrm{~cm}(0.39$ inch $)$ long, showing no sign of initiation of inflorescence that is visible to the naked eye, and (B) at $1.5 \mathrm{~cm}$ (0.59 inch) long, showing the first signs of early development of inflorescence that is visible to the naked eye.

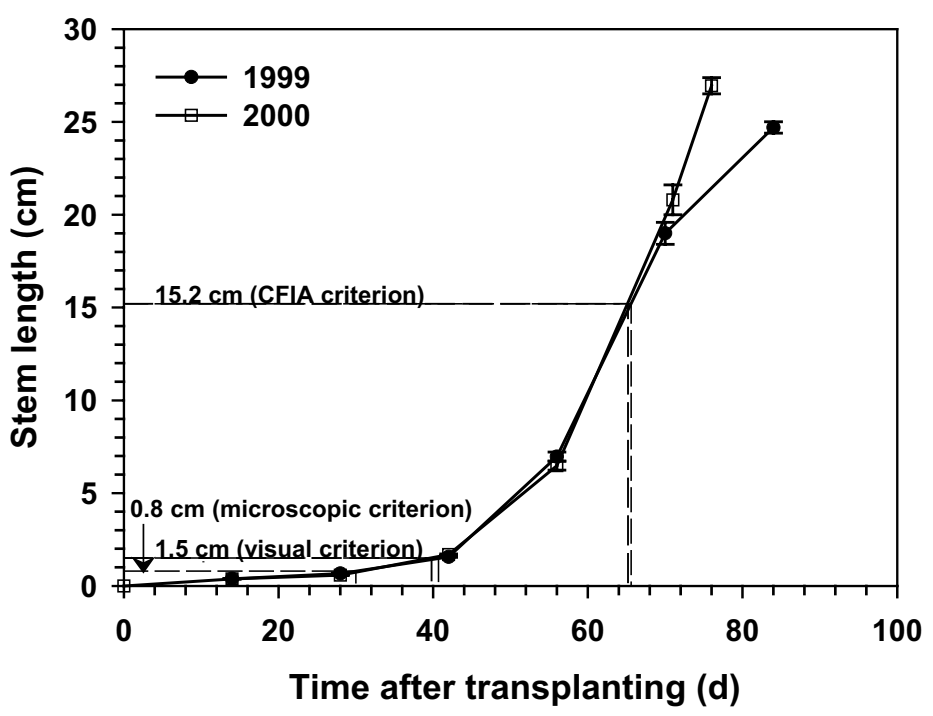

Fig. 2. Mean main stem length $( \pm S E)$ of vernalized 'Florida 683 ' celery throughout the 1999 and 2000 growing seasons at Sainte-Clotilde, Que. Dashed lines indicate the mean number of days after transplanting in the field until celery stems reached the microscopic $(0.8 \mathrm{~cm})$, visual $1.5 \mathrm{~cm})$ and Canadian Food Inspection Agency (CFIA) length $(15.2 \mathrm{~cm})$ thresholds $(1 \mathrm{~cm}=0.3937$ inch $)$.

on post-factor analysis, a recommended sample size should be 30 plants to detect a difference in stem length of 0.3 $\mathrm{cm}[\propto=0.05,(1-\beta)=0.8]$ based on the 1999 population, which had the widest variance. If the proportion of celery showing early signs of bolting appears to be high (above 10\%), an early harvest could be considered 65-66 d after transplanting to prevent mean stem length from exceeding the CFIA criterion of $15.2 \mathrm{~cm}$ (Fig. 2). Hence, celery growers would have had, using the visual criterion for inflorescence development, a period of $25 \mathrm{~d}$ and, using the microscopic criterion, a period of up to $35 \mathrm{~d}$ to plan to harvest earlier. According to the 1999 and 2000 data, an early harvest would have occurred
18 and $11 \mathrm{~d}$ before celery maturity, which was when the final harvest was actually performed.

Harvesting celery earlier to minimize losses due to bolting will have the inevitable consequence of producing lower grade celery [e.g., Canada No. 2 instead of Canada No. 1 (CFIA, 1999)]. For example, the fresh weight of celery harvested 65-66 d after transplanting vs. at crop maturity would have been $809 \mathrm{~g}$ instead of $957 \mathrm{~g}$ in 1999 , and $990 \mathrm{~g}$ instead of $1385 \mathrm{~g}$ in 2000 (data not shown). The decision to harvest earlier or to let the crop grow to maturity while assuming some losses due to bolting should be made on a case by case basis, essentially depending on 1 ) the detected proportion 
of plants induced to bolt, and 2) the current and expected market prices of the different grades of celery. Actually, the possibility of selling induced celery for hearts may bring a premium price, and this should be considered in the economic calculation. The method proposed here for early detection of bolting does provide celery growers with a sufficiently long period (up to 36 d) to weigh those factors and make the most profitable decision. Coupled with agro-economic studies, this method could prove to be effective in minimizing financial losses in years when weather conditions are propitious for bolting. Additional data are required to validate the model with celery vernalized under natural conditions, i.e., in the greenhouse during transplant production or after transplanting under field conditions.

\section{Literature cited}

Benoit, F., J.M. Kinet, and N. Ceustermans. 1978. Induction, suppression or prevention of vernalisation in self-blanching celery (Apium graveolens L. var. dulce). Agricultura 26:163-182.

Canadian Food Inspection Agency. 1999. Fruit and vegetable inspection manuals: Celery. 15 Apr. 2005. <http://www. inspection.gc.ca/english/plaveg/fresh/ vegleg/celery/celerye.shtml>.
Centre de référence en agriculture et agroalimentaire du Québec. 2001. Répertoire 2001-2002 des traitements de protection des cultures. Centre de référence en agriculture et agroalimentaire du Québec, Sainte-Foy, Que.

Environment Canada. 2005. National climate data and information archive. 26 Apr. 2005. <http://climate.weatheroffice. ec.gc.ca/climateData/canada_e.html>.

Honma, S. 1959. A method for evaluating resistance to bolting in celery. Proc. Amer. Soc. Hort. Sci. 74:506-513.

Kinet, J.M., F. Benoit, N. Ceustermans, and A. Parmentier. 1976. Environmental control of bolting and flowering in selfblanching celery (Apium graveolens L. var. dulce) by exposure to low temperature. Agricultura 24:347-358.

Pressman E. 1997. Celery, p. 387-407. In: H.C. Wien (ed.). The physiology of vegetable crops. CAB Intl., New York.

Pressman, E. and M. Negbi. 1980. The effect of day length on the response of celery to vernalization. J. Expt. Bot. 31:1291-1296.

Pressman, E. and M. Sachs. 1985. Apium graveolens, p. 485-507. In: A.H. Halevy (ed.). Handbook of flowering, Vol. I. CRC Press, Boca Raton, Fla.
Ramin, A.A. and J.G. Atherton. 1991. Manipulation of bolting and flowering in celery (Apium graveolens L. var. dulce). II. Juvenility. J. Hort. Sci. 66:709-717.

Ramin, A.A. and J.G. Atherton. 1994. Manipulation of bolting and flowering in celery (Apium graveolens L. var. dulce). III. Effects of photoperiod and irradiance. J. Hort. Sci. 69:861-868.

Roelofse E.W., D.W. Hand, and R.L. Hall. 1989. The effect of day length on the development of glasshouse celery. J. Hort. Sci. 64:283-292.

Roelofse E.W., P.T. Atkey, D.W. Hand, and R.L. Hall. 1994. A study by cryo-scanning electron microscopy of the initiation and early development of an inflorescence in glasshouse celery (Apium graveolens L. var. dulce (Miller) Pers.) grown under inductive conditions. Ann. Appl. Biol. $125: 553-566$.

Tremblay, N. and M. Sénécal. 1991. La production de plants maraîchers en plateaux multicellulaires. Conseil des productions végétales du Québec, Agdex 290/20. Quebec Dept. Agr., Fisheries and Food, Quebec. 